\title{
Aging and growth parameter from the Piaractus mesopotamicus (pacu) from the Cuiabá river, Mato Grosso, Brazil
}

\author{
Angela M. Ambrosio ${ }^{1}$, Thiago J. Balbi², Talitha M. Francisco³, Luiz C. Gomes 5 , Marina S. Zuliani ${ }^{4}$ \& \\ Edson K. Okada ${ }^{1}$
}

\footnotetext{
1. Núcleo de Pesquisas em Limnologia, Ictiologia e Aquicultura - Nupélia, Universidade Estadual de Maringá, Av. Colombo 5790, 87020-900, Maringá, PR, Brazil. (ambros@nupelia.uem.br) 2. Instituto Oceanográfico da Universidade de São Paulo - IOUSP. Praça do Instituto Oceanográfico, 191, Cidade Universitária, 05508-120, São Paulo, SP, Brazil.

3. Universidade Estadual do Norte Fluminense Darcy Ribeiro, Av. Alberto Lamego, 200, 28013-302, Campos dos Goytacazes, RJ, Brazil.

4. Universidade Estadual de Maringá, Av. Colombo 5790, 87020-900, Maringá, PR, Brazil.

5. Universidade Estadual de Maringá (DBI/Nupélia), Av. Colombo 5790, 87020-900, Maringá, PR, Brazil.
}

\begin{abstract}
This study has aims to determine the age and to estimate the growth parameters using scales of the species. Individuals of Piaractus mesopotamicus (Holmberg, 1887) used in this study were captured in the commercial fishery conducted in the region, along the year 2006 . The model selected to express the growth of the species was the von Bertalanffy $\mathrm{Sl}=\mathrm{S} 1 \infty^{*}\left[1-\mathrm{exp}^{-\mathrm{k}(\mathrm{t}-\mathrm{t})}\right]$. To determine if scales are suitable for studying the growth of pacu, we analyzed the relation between standard length $(\mathrm{Sl})$ and the radius of the scales through linear regression. The period of annuli formation was determined analyzing the variations in the marginal increment and evaluating the consistency of the readings through the analysis of the coefficient of variations (CVs) for the average standard lengths of each age (number of rings) observed in the scales. The relationship between Ls of the fish and the radius of the scales showed that scales can be used to study the age and growth of $P$. mesopotamicus $(\mathrm{R}=0.79)$. CVs were always below $20 \%$, demonstrating the consistency of the readings. Annuli formation occurred in February, probably related to trophic migration that occurs in this month in the region. Equations that represents the growth in length obtained for $P$. mesopotamicus are $\mathrm{Sl}=50.00^{*}\left[1-\mathrm{exp}^{-0.18\left(t-\mathrm{t}_{-3.00}\right.}\right]$ for males and $\mathrm{Sl}=59.23 *\left[1-\exp ^{-0.14(t--3.36)}\right]$ for females. The growth parameters obtained in this study were lower compared to other studies previously conducted for the same species and can related to overexploitation that species is submitted by fishing in the region. These values show also that females of pacu attain greater asymptotic length than males that growth faster.
\end{abstract}

KEYWORDS. Growth rings, scales, von Bertalanffy model, Ford-Walford.

\begin{abstract}
RESUMO. Estimativas dos parâmetros de crescimento e idade do Piaractus mesopotamicus (pacu) do rio Cuiabá, Mato Grosso, Brasil. Este estudo tem como objetivo determinar a idade e estimar os parâmetros de crescimento usando as escamas da espécie. Esta informação pode ser usada em outros estudos sobre dinâmica de estoques da espécie na área estudada. Os indivíduos do Piaractus mesopotamicus (Holmberg, 1887) usados nesse estudo foram capturados na pesca comercial, desenvolvida na região durante o ano de 2006. O modelo escolhido para analisar o crescimento da espécie foi o de Von Bertalanffy $\left(\mathrm{Cp}=\mathrm{Cp} \infty^{*}\left[1-\exp ^{-k(t-t o)}\right]\right.$. Para saber se as escamas são apropriadas para estudos de crescimento do pacu, nós analisamos a relação entre o comprimento padrão $(\mathrm{Cp})$ e o raio das através de regressão linear. O período de formação dos anéis foi determinado analisando as variações no incremento marginal e a consistência das leituras foi avaliada através da análise do coeficiente de variação (CVs) do comprimento padrão médio para cada idade (número de anéis) observado nas escamas. A correlação entre o Ls do peixe e o raio das escamas mostrou que as escamas podem ser utilizadas para estudos de crescimento do P. mesopotamicus $(\mathrm{R}=0.79)$. Os CVs foram sempre abaixo de $20 \%$ demonstrando consistência nas leituras. A formação dos anéis ocorreu em fevereiro provavelmente relacionada com a migração trófica que ocorre neste mês na região. As equações que representa o crescimento em comprimento obtidas para o $P$. mesopotamicus $\mathrm{são:} \mathrm{Cp}=50.00^{*}\left[1-\exp ^{-0.18\left(t-\mathrm{t}_{-3.00}\right.}\right]$ para machos e $C p=59.23 *\left[1-\exp ^{-0.14(t-(-3.36)}\right]$ para fêmeas. Os parâmetros de crescimento encontrados neste estudo foram mais baixos quando comparados com outros estudos para a mesma espécie realizados anteriormente e pode estar relacionado com "overexplotation" pela pesca que a espécie é submetida na área. Esses valores mostram ainda que as fêmeas do pacu atingem comprimentos assintóticos maiores que os machos que crescem mais rápido.
\end{abstract}

PALAVRAS-CHAVE. Marcas de aposição, escamas, modelo de von Bertalanffy, Ford-walford.

We know that all models used in the management of fishery require not only biomass of the stock but also the age structure, whereas growth parameters are used in the estimation of fish stocks (AraYA \& SverLiJ, 1999). They are fundamental components of most present-day fisheries management decisions (CAMPANA, 2001), however, age determination of fish in tropical regions is a challenge, given the fact that growth rings are not as evident as in temperate regions, where seasonal variation of temperature and luminosity are more conspicuous (SANTOS \& BARBIERI, 1993). Despite of the difficulties of this type of study (See Curtis, 1934 for details), Ferreira \& Russ, 1994; Fernandes et al., 2002; Dei Tos et al., 2010; Francisco et al., 2011, also affirmed that age structure and growth parameters are fundamental components in management decisions specially in the area studied (tropical regions). According FERREIRA \& Russ, 1994, the fish diversity is high, particularly the Characiformes and Siluriformes. RESENDE et al. (1996) discussed the great economic importance of them in the area studied.

Although a the importance of $P$. mesopotamicus in the fisheries in the Pantanal is great, basic information on the biology of the species are still not available, fact that difficult any assessment of its stocks and management actions. So, this study aims to determine the age and estimated the growth parameters of the von Bertallanfy model through readings of marks in scales of pacu. After, we analyzed the periodicity in ring formation and we used the coefficient of variation of mean standard length for each class to validate it. 


\section{MATERIAL AND METHODS}

Study area. Individuals of $P$. mesopotamicus were collected in the Cuiabá River, a tributary of the Paraguay River and Manso River, in the stretch under the influence of APM-Manso Reservoir (Fig. 1). This area is located above the Pantanal of Mato Grosso in the Mid-west region of Brazil. The Pantanal begins just after the municipalities of Cuiabá and Várzea Grande, where the Cuiabá River begins to increase in size (Oliveira et al., 2005). Following the longitudinal gradient of the studied stretch (reservoir - upper part of the Pantanal) (Fig. 1), we divided it in nine fishing areas (border of municipalities), as follow: Manso Reservoir, Chapada dos Guimarães, Nobres, Rosário Oeste, Acorizal, Cuiabá, Várzea Grande, Santo Antonio de Leverger and Barão de Melgaço.

The reservoir is located in the geographical coordinates $16^{\circ} 32^{\prime}-16^{\circ} 40^{\prime} \mathrm{S}$ and $54^{\circ} 40^{\prime}-55^{\circ} 55^{\prime} \mathrm{W}$, near the National Park of Chapada dos Guimarães. It was filled in 1999 and inundated a large area of the Manso River and the lower parts of the rivers Casca, Palmeiras and Quilombo. The APM-Manso reservoir is inserted in the municipalities of Chapada dos Guimarães and Nova Brasilândia and has an area of 42.700 ha in its maximum water level. The climate in the region is tropical with annual mean air temperature ranging between $22^{\circ} \mathrm{C}$ and $32^{\circ} \mathrm{C}$, and the average annual rainfall between $1100 \mathrm{~mm}$ and $1200 \mathrm{~mm}$ (HASENACK et al., 2003).

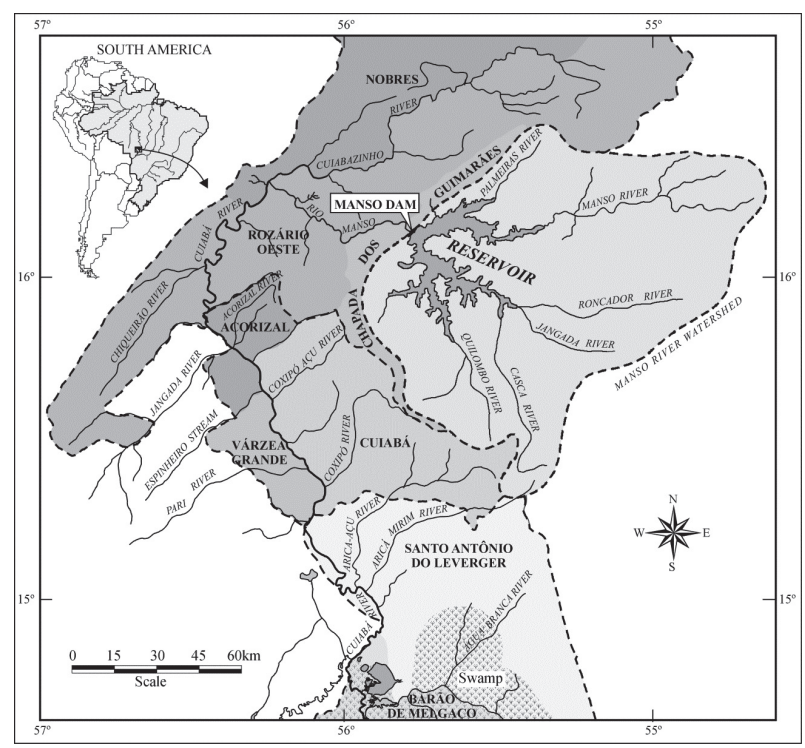

Fig. 1. Map of the the area where the scales were collected, Mato Grosso, Brazil.

Sampling procedure and data analysis. Individuals of P. mesopotamicus (606 individuals; 253 males and 353 females) were captured in the commercial (artisanal) fisheries conducted in the region (Manso Reservoir to the upper part of Pantanal), from January to December of 2006. In each of the nine fishing areas a detailed analysis of the captured fish was performed. The bone structure chosen was scales, collected in region located under the pectoral fin of each fish. These were removed and placed in envelopes including collector name, location of capture and number of the individual. For every fish, it was measured the standard length $(\mathrm{Sl} ; \mathrm{cm})$, total weight (Wt; g.), and determined their sexes.

In laboratory, scales were cleaned and mounted between glasses slides following VAzzoLER et al. (1982) and had their radius measured. To investigate if the scales can be used to study the growth of pacu, we analyzed the relation between the standard length of the fish and the radius of the scales, through linear regression. The age rings were identified under stereomicroscope with micrometric lens. A complete and well-defined translucent zone was considered to be a growth rings or annulus (CASSELMAN, 1983). We conducted three readings of all scales and only the ones in which the number of growth rings was the same in two readings were included in the analysis.

Before conducting the other analysis, we have to verify if males and females grow similarly. To evaluate that, we calculated the total weight $(\mathrm{Wt}) \mathrm{x}$ standard length (Sl) relationship for each sex through the methods proposed by (Le CREN, 1951), using expression:

$\mathrm{Wt}=\mathrm{a} * \mathrm{Sl}^{\mathrm{b}}$, where: $\mathrm{Wt}=$ total weight $(\mathrm{g}) ; \mathrm{Sl}=$ standard length $(\mathrm{cm}) ; \mathrm{a}=$ intercept; $\mathrm{b}=$ slope.

To verify if males and females of $P$. mesopotamicus presented different length $\mathrm{x}$ weight relationship, we performed an ANCOVA (Sl log 10 and Wt $\log 10$ transformed to meet the assumption of linearity), using the software Statistica 7.1 (Statsoft Inc., 2005). First we tested the assumption of parallelism of the ANCOVA (same slope). If not met, we conducted a separate-slope model analysis.

After confirming if sex has to be dealt together or separated, the consistency of the readings was evaluated through the analysis of the coefficient of variations (CVs) for the standard lengths average of each age class observed in the scales (LAI et al., 1996).

The period of annuli formation was determined by marginal increment analysis, which may be considered a method to validate the age observed in a bone structure (proposed by LAI et al., 1996), as follow:

$$
I=\frac{R-R_{i}}{R_{i}-R_{i-1}} * 100 \text {, where: } \mathrm{R}: \text { distance between the }
$$

of the scales (scale radius); $R_{i}$ : distance between the last annuli and the edge of the scale; $\mathrm{R}_{\mathrm{i}-1}$ : distance between the penultimate annuli and the edge of the scale.

The model selected to express the growth of $P$. mesopotamicus was the von Bertalanffy (BERVERTON \& HoLt, 1957), fitted using the Ford-Walford transformation (WALFORD, 1946). This transformation was selected because results can be compared with other studies on the same species in other regions. After estimating the parameters $\mathrm{k}$ (growth rate) and $\mathrm{Sl}_{\infty}$ (asymptotic standard length), it was possible to determine the growth curve in length ( $\mathrm{K}$ and $\mathrm{Sl}_{\infty}$ are the parameters of the von Bertallanfy model), described by the expression:

$\mathrm{Sl}=\mathrm{Sl}_{\infty}\left[1-\mathrm{e}^{-\mathrm{k}(\mathrm{t}-\mathrm{to})}\right]$, where: $\mathrm{Sl}=$ standard length of 
the individuals with age " $\mathrm{t}$ " $(\mathrm{cm}) ; \mathrm{Sl}_{\infty}=$ maximum standard (asymptotic) length that individuals can achieve $(\mathrm{cm}) ; \mathrm{e}=$ neperian logarithm; $\mathrm{k}=$ parameter related to growth rate $\left(\right.$ year $\left.^{-1}\right) ; \mathrm{t}=$ age of individuals (years); $\mathrm{t}=$ age at which the individual would have had size equal zero.

The parameter $t_{0}$ was estimated using the expression presented in VAzzoler (1981). To obtain the growth curve in weight, we solved the length $\mathrm{x}$ weigh relationship for the asymptotic length $\left(\mathrm{Sl}_{\infty}\right)$, estimating the asymptotic total weight $\left(\mathrm{Wt}_{\infty}\right)$.

Then, we determined the equation which represents the growth in weight of the species, using the direct method described by ANTONiUtTi et al., 1985 and also used by AmBrósio et al., 2003, as follow:

$\mathrm{Wt}=\mathrm{Wt}_{\infty} *\left[1-\exp ^{-\mathrm{k}(\mathrm{t}-\mathrm{t}(\mathrm{o})}\right]^{\mathrm{b}}$, where: $\mathrm{Wt}=$ total weight; $\mathrm{Wt}_{\infty}=$ asymptotic total weigh; $\mathrm{K}$ and $\mathrm{t}_{\mathrm{o}}=$ parameters of the von Bertallanfy equation; $b=$ slope of the relationship between total weight and standard length.

\section{RESULTS AND DISCUSSIONS}

In this study, the maximum of seven growth rings were found in the scales of males and females. However, individuals with 3 and 4 rings in the scales were more abundant (totaling 450 individuals).

The choice of the most appropriate bone structure to estimate age is not an easy task. To evaluate if the structure can be used, we must take into account the degree of accuracy required regarding the age estimation and the phase of the life cycle to be studied (Morales-Nin \& PantifiLi, 2001). It should also be considered that the growth increments are easily distinguishable and identifiable, have constancy in their periodicity and present the same synchronicity in any population. In this study, scales were chosen because their preparation, collection, and analysis are easier; their removal also does not require sacrifice of the animal (CASSElman, 1983; Isely \& Grabowski, 2007). In our case, the removal of the scales did no alter the appearance of the fish to be sold on local markets. In addition, the linear relationship between the standard length of fish ( $\mathrm{Sl})$ and the radius of the scale was significant $(\mathrm{F}$ $=949.3 ; \mathrm{p}<0.01)$ and the Pearson correlation was equal 0.79 . The anti-log model that describes this relationship is:

$\mathrm{Sl}=0.08^{*} 8.7^{\mathrm{x}}$. Thus, these results show that the scales of P. mesopotamicus can be used to study its age because as the fish grows, the scales also grow proportionally, indicating that marks in the scales can be assigned to growth rings.

The assumption of parallelism for the ANCOVA was not met $(p<0,05)$, indicating that the slopes of the length * weight relationship are different between sexes. Then, we conducted the separate-slope model analysis (Fig. 2). The anti-log models that describe this relationship are: $\mathrm{Wt}=0.186 * \mathrm{Sl}^{2.54}(\mathrm{R}=0.91)$ for males and $\mathrm{Wt}=0.093 *$ $\mathrm{SL}^{2.74}$ for females $(\mathrm{R}=0.92)$. This relationship allows an estimate of the weigh from length and vice-versa. According LE CREN, 1951, the values of "b" in fishes vary between
2.5 and 4.0. So, the values found for P. mesopotamicus in Cuiabá River are within these values. Differences in growth of males and females are well reported in the literature; females grew faster and get greater sizes in several fish species (VAZZOLER, 1996), with purpose to maximize egg production (WоOTTON, 1990).

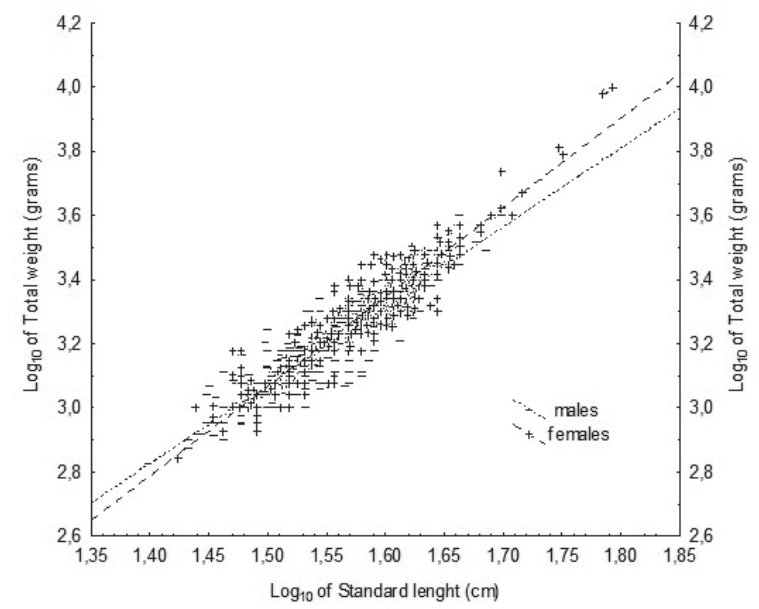

Fig. 2. Graphical representation of the $\log _{10}$ of total weight and $\log _{10}$ of standard length for males and females of Piaractus mesopotamicus (Holmberg, 1887) collected in Cuiabá River, state of Mato Grosso, Brazil, in 2006.

In all studies of age and growth, it is mandatory to validate growth rings, to obtain unbiased estimates of the parameters for the von Bertalanffy model (CASSELMAN, 1983; Cyterski \& Spangler, 1996; Jepsen et al., 1999; Francisco et al., 2011). In the review of Dei Tos et al., 2010, it is show that $52.9 \%$ of the aged species of South America did not have their data on age validated as recommended by Campana (2001). Dei Tos et al. (2010) argument that this lack of validation is probably because, for the fish of the Neotropical region, it requires the application at least two methods. Most studies analyzed by the same authors, validated growths rings using the mean length of the fish with the same number of rings along time (19.6\%), followed the analysis of marginal increment (18.3\%).

We know that the process of estimating age incorporates biases associated with the non-formation of rings as fish grow, and these biases can lead to under or overestimated ages (CAMPANA, 2001). This author also alert the existence of subjectivity in the estimates of age or accuracy [(interpretation of the numbers of rings and precision (numbers of fish studied)]. Thus, to evaluate these problems, we used the coefficient of variation (CV) of the standard length of fish with the same number of rings. In this study, values of CV were considered low (below 20\%; Tab. I) attesting the consistency of the readings (number of rings in the scales), and reinforcing that scales can be used to estimate age and growth parameters of P. mesopotamicus (Witherel \& BuRNetT, 1993). CAMPANA (2001) also affirms that $\mathrm{CVs}$ are a statistically sound measure of aging precision in fish, but he calls attention because CV may be influenced by the species, the bone structure analyzed, as well as the reader. 
Tab. I. Sample size $(\mathrm{N})$, mean standard length $(\mathrm{Ls}, \mathrm{cm}$ ) for each age group and coefficient of variation $(\mathrm{CV})$ of the mean standard length observed for each ring, for males and females of pacu Piaractus mesopotamicus (Holmberg, 1887) collected in 2006 in Cuiabá River, state of Mato Grosso, Brazil.

\begin{tabular}{cccccccc}
\hline Machos & \multicolumn{7}{c}{ Fêmeas } \\
\hline Idade & $\mathrm{N}$ & $\begin{array}{c}\text { Ls } \\
\text { médio }\end{array}$ & $\mathrm{CV}$ & Idade & $\mathrm{N}$ & $\begin{array}{c}\text { Ls } \\
\text { médio }\end{array}$ & $\mathrm{CV}$ \\
1 & 5 & 24.64 & 15.14 & 1 & 4 & 27.50 & 15.14 \\
2 & 35 & 30.89 & 7.21 & 2 & 29 & 30.80 & 7.21 \\
3 & 117 & 33.79 & 9.73 & 3 & 124 & 34.90 & 9.73 \\
4 & 74 & 35.97 & 8.47 & 4 & 131 & 38.59 & 8.47 \\
5 & 19 & 37.85 & 10.43 & 5 & 58 & 41.67 & 10.43 \\
6 & 1 & 39.8 & --- & 6 & 4 & 43.60 & --- \\
7 & 2 & 42 & 13.47 & 7 & 3 & 45.10 & 13.47 \\
\hline
\end{tabular}

The least average of the marginal increment in the scales occurred in February 2006, indicating that one ring is formed annually (Fig. 3). The formation of only one growth ring is considered common for fish from the Neotropical region (AmBrósio et al., 2003; FrANCISCO et al., 2011).

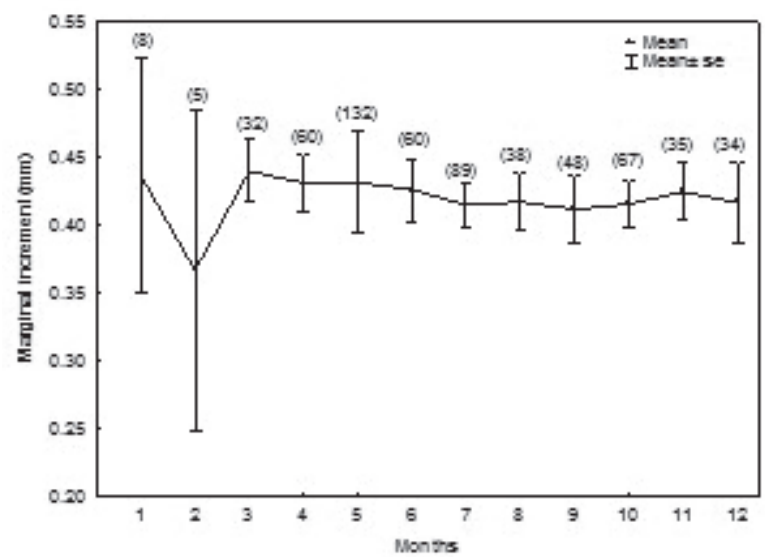

Fig. 3. Monthly variation in the mean marginal increment \pm standard error (SE), observed in scales of Piaractus mesopotamicus (Holmberg, 1887) collected in 2006 in Cuiabá River, state of Mato Grosso, Brazil (numbers in bracket are sample size for each month).

The formation of rings in the Neotropics is usually associated with spawning (GIRARD et al., 2003; FEITOSA et al., 2004). DEI Tos, et al. (2010) found the same explanation for ring formation in $40.7 \%$ of the studies they analyzed. During this period, species allocate energy for gonadal maturation, migration towards appropriate habitats for spawning. However, other factors may affect fish growth, such as pluviometric level (CUTRIM \& BATISTA, 2005), temperature and variation in rainfall (MAteus \& Petrere JR, 2004; Araya et al., 2008). For P. mesopotamicus we determined that growth rings are formed in February and they appear to be related to the trophic migration in the region, which usually occurs in February (Fig. 3), as already discussed by PEIXER et al. (2007) studying the same species below the study area.

Females presented greater asymptotic length than males (59.23 $\mathrm{cm}$ and $50.00 \mathrm{~cm}$, respectively). However, the growth rate $(\mathrm{K})$ presented opposite tendency $\left(0.14\right.$ year $^{-1}$ for females and 0.18 year $^{-1}$ for males (Fig. 4).

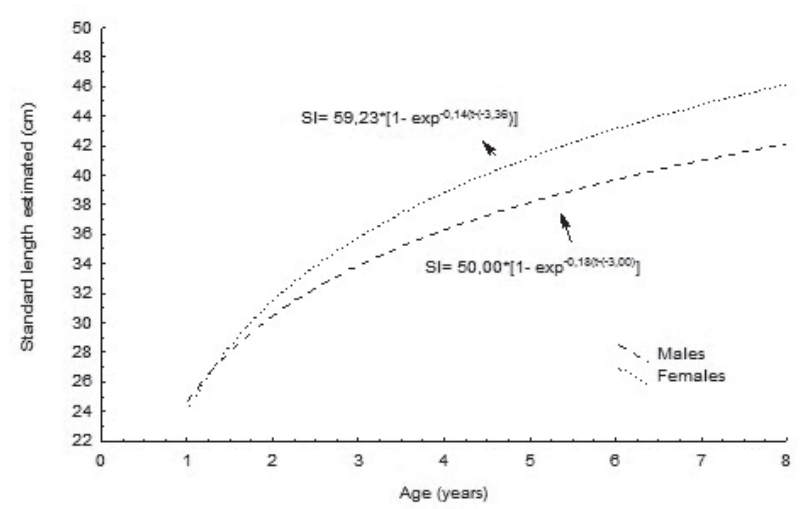

Fig. 4. Growth curves in length for males and females of Piaractus mesopotamicus (Holmberg, 1887) collected in 2006 in Cuiabá River, state of Mato Grosso, Brazil.

are harvested at an average size that is smaller than the size that would produce the maximum yield per recruit. This makes the total yield less than it would be if the fish were allowed to grow to an appropriate size. PAULY, 1983 affirm it can be countered by reducing fishing mortality to lower levels and increasing the average size of harvested fish to size that will allow maximum yield per recruit.

Piaractus mesopotamicus is a species considered a long-distance migrant (RESENDE, 2003) and identified as seasonal strategy by WiNEMILLER, 1989, like others large Characiformes. So, this species has a burst of reproduction with the early rains, followed by gradual reduction in population size due largely to predation on immature in the early dry season (WINEMILLER, 1989). The adults moving downstream to spawn in floodplains during the wet season (Reproductive migration), moving upstream more later to escape from predation and the harsh conditions of floodplain during the dry season (Trophic migration). As mentioned above, this period probably the emergence of a new growth rings for species.

To obtain the asynmptotic weight we solved the equations $\mathrm{Wt}_{\infty}=0.093 * 50^{2.54}$ for males and $\mathrm{Wt}_{\infty}=$ $0.186 * 59.23^{2.74}$ for females for the asymptotic length $\left(\mathrm{Sl}_{\infty}\right)$ (AnTONiutti et al., 1985). These values were: $3845 \mathrm{~g}$ for males and $6688 \mathrm{~g}$ for females. Then, the equations that represent the growth in weigh are: $\mathrm{Wt}_{\infty}=3845 *\left[1-\right.$ exp $^{-}$ $0.18(\mathrm{t}-(-3.00)]^{2.54}$ for males and $\mathrm{Wt}_{\infty}=6688^{*}\left[1-\exp ^{-0.14(\mathrm{t}-(-3.36)}\right]^{2.76}$ for females.

Acknowledgements. We thank the Nupélia (Núcleo de Pesquisas em Limnologia, Ictiologia e Aquicultura) for logistic support which facilitated the sampling and analysis of fish and Furnas Centrais Elétricas for financing the study. We also thank the researchers AAA and LCG.

\section{REFERENCES}

Ambrósio, A. M.; Gomes, L. C. \& Agostinho, A. A. 2003. Age and growth of hypophthalmus edentatus (Spix \& Agassiz, 1829) (Siluriformes, Hypophthalmidae) in the Itaipu Reservoir, Paraná, Brazil. Revista Brasileira de Biologia 20(2):183-190.

Antoniutti, D. M.; Ranzini-Paiva, M. G. T.; Godinho, H. M. \& Paiva, P. 1985. Relação peso total/comprimento total, crescimento e idade do cascudo Plecostomus albopunctatus Regan, 1908 (Osteichthyes, Loricarridae) do rio Jaguari, São Paulo, Brasil. Boletim do Instituto de Pesca 12(4):105-120. 
Araya, P. R. \& Sverli, S. B. 1999. Edad y crecimiento de Prochilodus scrofa (Characiformes, Prochilodontidae) em el alto rio Paraná. Iheringia, Série Zoologia (86):45-54.

Araya, P. R.; Agostinho, A. A. \& Bechara, J. A. 2008. Population structure, growth and fishery yield of Leporinus acutidens (Valenciennes, 1837) (Teleostei: Anostomidae) in Yacyretá Reservoir (Argentina). Neotropical Ichthyology 6(1):57-66.

Berverton, R. F. H. \& Holt, S. F. 1957. On the dynamics of exploited fish populations. London, Hermajestys Stationery Office. Fishery Investigations, lave Success, 10. 533p.

Campana, S. E. 2001. Accuracy, precision and quality control in age determination, including a review of the use and abuse of age validation methods. Journal of Fish Biology 59:197-242.

Casselman, J. M. 1983. Age and grow assessment of fish from their calcified structures - techniques and tools. U. S Department of Commerce, NOAA (National Oceanic and Atmospheric Administration) Technical Report NMFS (National marine Fisheries service) 8:1-6.

CurTis, B. 1934. The golden trout of Cottonwood lakes (Salmo aguabonita Jordan). Transactions of the American Fisheries Society 64:259-265.

Cutrim, L. \& BATISTA, V. S. 2005. Determinação de idade e crescimento do mapará (Hypophthalmus marginatus) na Amazônia Central. Acta Amazonica 35(1):85-92.

Cyterski, M. J. \& Spangler, G. R. 1996. A tool for age determination. North American Journal of Fisheries Management 16:403-412.

Dei Tos, C.; Gomes, L. C.; Ambrósio, A. M. \& Goulart, E. 2010. An overview of freshwater fish aging in South America: the science biases and future directions. Acta Scientiarium, Biological Sciences 32(4):323-333

Feitosa, L. A.; Fernandes, R.; Gomes, L. C. \& Agostinho, A. A. 2004. Parâmetros populacionais e simulação do rendimento por recruta de Salminus brasiliensis (Cuvier, 1816) do alto rio Paraná. Acta Scientiarum, Biological Sciences 26(3):317-323.

Fernandes, R.; Ambrósio, A. M. \& OKadA, E. K. 2002. Idade e crescimento de Satanoperca pappaterra (Heckel, 1840) (Osteichthyes, Cichlidae) no reservatório de Itaipu, Estado do Paraná. Acta Scientiarum, Biological Sciences 24(2):445-450.

Ferraz de Lima, J. A.; Ferraz de Lima, C. L. B. \& Barbieri, G. 1984. Crescimento do pacu (Colossoma mitrei), em ambiente natural (rio Cuiabá - Pantanal de Mato grosso). In: Peixer, J. \& Petrere $\mathrm{J}_{\mathrm{R} .}, \mathrm{M}$. eds. Hook selectivity of the pacu Piaractus mesopotamicus (Holmberg, 1887) in the Pantanal, the state of Mato Grosso do Sul, Brazil. Brazilian Journal of Biology 67(2):339-345.

Ferreira, B. P. \& Russ, G. R. 1994. Age validation and estimation of growth rate of the coral trout (Plectropomus leopardus (Lacépede 1802) from Lizard Island Northern Great Barrier Reef. Fishery Bulletin 92(1):46-57.

Francisco, T. M.; Ambrósio, A. M.; Balbi, T. J.; Zuliani, M. S.; Okada, E. K. \& Gomes, L. C. 2011. Age and growth parameters of cachara Pseudoplatystoma reticulatum (Siluriformes, Pimelodidae) from the Cuiabá River, Brazil. Iheringia, Série Zoologia 100(4):304-309.

Girard, P.; Silva, C. \& ABdo, M. 2003. River-groundwater interactions in the Brazilian Pantanal: case of the Cuiabá River. Journal of Hydrology 283:57-66.

Hasenack, H.; Cordeiro, J. L. P. \& Hofmann, G. S. 2003. O clima da RPPN SESC Pantanal. Relatório Técnico. Porto Alegre, Universidade Estadual do Rio Grande do Sul. 31p.

Isely, J. J. \& Grabowski, T. B. 2007. Age and growth. In: Guy, C. S. \& Brown, M. T. eds. Analysis and interpretation of freshwater fisheries data. Bethesda, America Fisheries Society, p. 187-228.

Jepsen, D. B.; Winemiler, K. O.; TAPHorn, D. C. \& Olarde, D. R. 1999. Age structure and growth of peacock cichlids from rivers and reservoirs of Venezuela. Journal of Fish Biology 55(2):433-450.

Lai, Han-Lin; Gallucci, V. F.; Gunderson, D. R. \& Donnelly, R. F. 1996. Age determination in fisheries: Methods and applications to shock assessment. In: Gallucci, V. F.; Saila, S. B.; Gustafson, D. J. \& RотнSCHILD, B. J. eds. Stock assessment: quantitative methods and applications for small-scale fisheries. Lewis, Publishers, p. 82-170.

Le Cren, E. D. 1951. The length-weight relationship and seasonal cycle in gonad weight an condition in the Perch (Perca fluviatilis). Journal of Animal Ecology 20:201-219.

Mateus, L. A. \& Petrere JR, M. 2004. Age, growth and yield per recruit analysis of the pintado Pseudoplatystoma corruscans (Agassiz, 1829) in the Cuiabá River basin, Pantanal Matogrossense, Brazil. Brazilian Journal of Biology 64(2):254-264.

Morales-Nin, B. \& Pantifili, J. 2001. Sclerochronological studies A-Age estimation. In: Pantifili, J.; Pontual, H.; Troadec, H. \& WrigTH, P. eds. Manual of fish sclerochronology. Brest, IfremerIRD coedition, $464 \mathrm{p}$.

Oliveira, M. T.; Nachp, A. M.; Vechi JR., K.; Santana-Porto, E. A. \& DuARTE, J. A. 2005. Determinação do ciclo reprodutivo de peixes reofílico de interesse comercial da sub-bacia do rio Cuiabá. Available at: $<$ http.//www.seb-ecologia.org.br/viiceb/resumos/339. pdf > . Accessed on: 30.10 .2013

PAULY, D. 1983. Some simple methods for the assessment of tropical fish stocks. FAO Fisheries technical paper. 234p.

Peixer, J. \& Petrere Jr., M. 2007. Hook selectivity of the pacu Piaractus mesopotamicus (Holmberg, 1887) in the Pantanal, the state of Mato Grosso do Sul, Brazil. Brazilian Journal of Biology 67(2):339-345.

Peixer, J.; Catella, A. C. \& Petrere JR., M. 2007. Yield per recruit of pacu Piaractus mesopotamicus (Holmberg, 1887) in the pantanal of Mato Grosso do Sul, Brazil. Brazilian Journal of Biology 67(3):561-567.

Resende, E. K. 2003. Migratory fishes of the Paraguay-Parana Basin excluding Upper Paraná River. In: CARolsfeld, J.; HaRvey, B.; Ross, C. \& BAERS, A. eds. Migratory Fishes of South America: biology, fisheries and conservation states. World Bank, Victoria, p. 99-155.

Resende, E. K; Pereira, R. A. C.; Almeida, V. L. L. \& Silva, A. G. 1996. Alimentação de peixes carnívoros da planície inundável do rio Miranda, Pantanal, Mato Grosso do Sul, Brasil. Corumbá, EMBRAPA (CPAP Boletim de Pesquisa 03). 36p.

SAntos, G. B. \& BARBIERI, G. 1993. Idade e crescimento do "piau gordura", Leporinus piau Folwer, 1941, na represa de Três Marias (Estado de Minas Gerais) (Pisces, Ostariophysi, Anostomidae). Revista Brasileira de Biologia 53(4):56-76.

STATSOFT, INC. 2005. Statistica for Windows (Data analysis Software System), version 7.1. Statsoft, Tulsa, Oklahoma.

VAZ, M. M. 2001. Problemas no ajuste da curva de crescimento do pacu, Piaractus mesopotamicus (Holmberg, 1887) (Pisces: Characidae), e seu manejo no pantanal mato-grossense. In: PeiXer, J. \& Petrere JR., M. eds. Hook selectivity of the pacu Piaractus mesopotamicus (Holmberg, 1887) in the Pantanal, the state of Mato Grosso do Sul, Brazil. Brazilian Journal of Biology 67(2):339-345.

VAzzoler, A. E. A. M. 1981. Manual de métodos para estudos biológicos de população de peixes: reprodução e crescimento. Brasília, CNPq Programa Nacional de Zoologia. 106p.

1996. Biologia da reprodução de peixes teleósteos: teoria e prática. Maringá, EDUEM, 169p.

Vazzoler, A. E.A. M; Wongtschowiski, C. L. B. R. \& Braga, F. M. S. 1982. Estudos sobre estrutura, ciclo de vida e comportamento de Sardinella brasiliensis (Steindachner, 1879), na área entre $220 \mathrm{OS}$ e 280S, Brasil. 4. Crescimento: aspectos quantitativos. Boletim do Instituto Oceanográfico 35(1):55-63.

WALFORD, L. A. 1946. A new graphic method the growth of animal. Biology Bulletin 90(2):141-147.

WinemiLLeR, K. O. 1989. Patterns of variation in life history among South American fishes in seasonal environments. Oecologia 81:225:241.

Witherel, D. B. \& BuRnetT, J. 1993. Growth and maturation of winter flounder, Pleuronectes americanus, in Massachusetts. Fishery Bulletin 91(4):816-820.

Wootton, R. J. 1990. Ecology of teleost fishes. London, Chapman \& Hall. $404 p$. 